\title{
Perspectives on Higher Education Accreditation from Portugal and the United States: An Evolving Process
}

\author{
Dennis Gregory \\ Old Dominion University \\ United States of America
}

\author{
Maria de Lourdes Machado-Taylor \\ Center for Higher Education Policies \\ Portugal
}

\begin{abstract}
University accreditation systems have become ubiquitous around the world as nations have sought to assure the quality of the institutions of higher/tertiary education within their borders and as institutions that are part of broader higher education systems are competing for students. In addition, many countries are seeking to increase the number of college graduates in their populations as the postindustrial world and knowledge economy grows and massification of higher education becomes more important as an economic tool. Moreover, tuition fees are being charged in countries where this has never been the case before and these countries are getting pressure from students and parents to insure the quality of their education. Thus, the accreditation systems in both countries are in flux. This paper addresses different perspectives of higher education accreditation systems at the Portuguese (European) and American level. There are considerable differences between the systems.
\end{abstract}

\section{Introduction}

We are in the Age of Knowledge where higher education (HE) has never had a more important role throughout the world. Nevertheless, higher education should represent one of the most exciting growth industries of the $21^{\text {st }}$ Century. However, HE no longer resides in a comfortable, secure place of privilege, one step removed from the competitive realities of modern society. Thus, this competitive environment in time is going to expose the shortcomings of the current higher education system. Moreover, powerful forces are driving higher education toward change [1]. As stated by Stensaker [2] " [...] universities and colleges are also exposed to stronger external accountability claims forcing them to legitimize themselves as integrated organizations fully in control of their operations." And the author continues stressing the role of HEIs [ ...] increasing number of expectations directed at higher education institutions in general, and universities in particular, especially as a result of the growing importance of knowledge and research as a foundation for innovation and economic growth [3]. In essence, universities are currently engaging more stakeholders, more expectations and undertake more activities than ever before [2].

In Europe today the agenda of $\mathrm{HE}$ is being dominated by the creation of the European Higher Education Area and the Bologna Process. Nevertheless several respected authors contend there is an increasing emphasis on mechanisms of accountability, new public management and competition, accompanied by the loss of trust in institutions [3]. Portugal as a member of the European Union is under the scrutiny of quality and effectiveness as well [4].

Accreditation has for many years been an important element in institutions of higher education in the United States, and within the last twenty years has taken on growing significance around the world as nations have sought to improve their tertiary education institutions and broaden the bodies of students they seek to enroll [6] [7] [8]. The United States, unlike other nations, has chosen to allow accreditation to be performed by six private regional accrediting agencies, though during the Bush administration there were efforts by the Secretary of Education, Margaret Spellings to centralize accrediting to the federal government, or to at least create a more uniform method of doing so across the country. These efforts raised a fire storm of controversy and criticism and the efforts had little long term effect on centralization but did result in the regional accreditation agencies seeking to "ramp up" their standards and accreditation focuses [9] [10].

Current issues of controversy lie in the area of accreditation of for-profit or proprietary institutions. Many of these institutions are not regionally accredited by choice, but are rather "nationally" accredited. This national accreditation will be explained below. Other proprietary institutions are regionally accredited but there have been allegations that these institutions try to pick a regional accreditation agency which it is believe will allow for an easier accreditation process. However, these institutions claim that they are simply seeking a regional agency where there are more like institutions so that a fair and equal accreditation process can take place [11] [12]. 
In Europe, the primary emphasis on increasing accreditation rigor has come from the various central governments and from the universities themselves [13] [14]. Nevertheless, accordingly to Vèbra and Scheuthle "While the Bologna Process stands for the European Higher Education Area, the European Standards and Guidelines (ESG) and the European Quality Assurance Register (EQAR) are its equivalent for quality assurance [5]. The objective is a common methodological base for quality assurance in Europe (ESG) and to allow quality assurance agencies to operate throughout Europe (EQAR). Thus, in terms of external quality assurance, higher education institutions (HEI) and quality assurance agencies operate in an environment with similar basic structures. Whereas the methodological base is already widely accepted, the European market for quality assurance is only developing. Most countries still have a national quality assurance system that is implemented by one or several national agencies. Even if foreign agencies are admitted in principle, external quality assurance remains predominantly national” [5].

There has also been pressure from the European Union and a desire to make Europe in general and a variety of countries in particular desirable locations to which international students come for study. Efforts to broaden the number and types of students who study in tertiary education, desire to strengthen tertiary education in those countries which have become net exporters of students, the creation of a common higher education framework as envisioned at Bologna, the inclusion of degree programs, particularly graduate programs, being offered in English, and to be competitive with the American system as well have occurred [15]. Nevertheless, the implementation of the Europe 2020 strategy rests with member states and education institutions themselves. The main responsibility for delivering and supporting reforms in higher education rests there in order to step up efforts to increase higher education attainment levels. This is true, in order to achieve education headcount target of $40 \%$ of $30-34$ year olds in the EU having completed tertiary or equivalent education. This is necessary since there is an estimate that by 2020,35\% of all jobs in the EU will require high-level qualifications. However, these efforts have moved less quickly of late in the countries of Southern Europe such as Portugal, due to political considerations and the poor economic conditions resulting from the world recession. While this is true, Portugal has a dynamic accreditation system - A3ES - and several good tertiary institutions which attract students from Portuguese speaking nations in Africa and from the dynamic and growing economy of Brazil and other European countries.

As noted above, rankings have become an important consideration by universities in many countries including the U.S. and throughout Europe. Thus, accreditation and assessment of these institutions has taken on a new direction and a growing importance. .According to Hazelkorn "Rankings are a manifestation of what has become known as the worldwide 'battle for excellence', and are perceived and used to determine the status of individual institutions, assess the quality and performance of the higher education system and gauge global competitiveness” [16].

This article will describe the accreditation systems within the United States and Portugal with an eye to comparisons and contrasts between the two systems.

\section{Accreditation in the United States of America}

Accreditation has for many years been an important element in institutions of higher education in the United States, and, in fact, according to Eaton has been in existence in the U.S. for over one hundred years [17]. As suggested above, within the last twenty years accreditation has taken on growing significance around the world, as nations have sought to improve their tertiary education institutions and broaden the bodies of students they seek to enroll. In addition, pressure has come from national governments and in some cases from external bodies such as the European Union. This has increasingly been so within those countries in the European Union (EU) and others who have joined in to be part of and support the Bologna Process and subsequent development of the European Higher Education Area, and their goals as well as other educational programs instituted by the EU. Program quality, institutional effectiveness, graduation rates, financial efficiency, and student support systems have been a large part of these foci, and the flattening of the world and competition for students from Asia and India as well as decreases in funding support have sharpened these efforts. While we will describe these model in Portugal later in this paper, this portion will focus upon the models that exist within the United States.

As noted earlier, the United States, unlike many other nations, has chosen to allow its primary accreditation to be performed by six regional accrediting agencies. While this is true, efforts to increase effectiveness and make the systems more alike have occurred [18].

As a background, the United States has an extremely large and diverse post-secondary education system. There are approximately 8200 institutions of post-secondary education, about half of which are either publically funded institutions or privately funded institutions, all of which are not for profit. The remaining institutions are for profit or 
proprietary private institutions, which may be "closely held" (owned by one person, a family or other small group) or "publically held" (they may be traded on the stock market and may be parts of a large network of colleges owned by one corporation). Both proprietary and not-for-profit institutions vary widely in size and sophistication.

This "regional accreditation" process is the most detailed and broadly accepted accreditation system in the U.S., and such accreditation requires detailed examination of a broad cross-section of institutional organization, curriculum and operations. However, many proprietary institutions have chosen to forgo regional accreditation and have opted to choose "national" accreditation. National accreditation is often less rigorous and is performed by agencies and organizations that focus upon particular types of institutions, such as those focused on a particular career emphasis. Nationally accredited institutions may focus on a very narrow career training program such as training barbers and hair stylists and may be very small, having less than five faculty and fewer than fifty students. These programs do not grant academic degrees, but often provide certificates and other credentials to qualify the student for a career.

Accreditation in one form or another, approved by the U.S. Department of Education, is necessary for institutions to qualify for their students to receive federal financial aid. While national accreditation of institutions meets this requirement and these institutions are able to provide associates (two-year) degrees, baccalaureate (four-year) degrees, and even some graduate degrees, courses taken and degrees earned from these institutions often do not allow a student to transfer credits to a not-for-profit institution, or to use acquired degrees as qualifications for admission to a higher level degree program.

According to Judith Eaton, President of CHEA, there are six trends which are impacting accreditation in the United States at the moment [17]. These are:

1. The driving force of accountability,

2. The growing dominance of government,

3. The advance of a utilitarian approach to higher education,

4. The impact of innovation or 'disruptive technologies',

5. The increasing importance of international quality assurance and,

6. A questioning of the faith in the core values that have been at the centre of accreditation. [17]

\subsection{Regional accreditation}

As indicated earlier, regional accreditation is considered the most prestigious type of accreditation in the U.S., and is performed by one of six private accreditation agencies. All of these accrediting agencies are overseen by the Council for Higher Education Accreditation (CHEA). These regional agencies include:

1. Southern Association of Colleges and Schools (SACS) Commission on Colleges

2. Middle States Commission on Higher Education (MSCHE)

3. New England Association of Schools and Colleges Commission on Institutions of Higher Education (NEASC-CIHE)

4. North Central Association of Colleges and Schools. The Higher Learning Commission (NCA-HLC)

5. Western Association of Schools and Colleges WASC Senior College and University Commission, and

6. (WASC-SCUC) Western Association of Schools and Colleges Accrediting Commission for Community and Junior Colleges (ACCJC-WASC).

CHEA also oversees the national accreditation process including National Faith Based Accrediting Organizations, National Career-Related Accrediting Organizations and Programmatic Accrediting Organizations. Programmatic Accrediting Organizations are essential in the U.S process for both for-profit and not-for-profit institutions. These organizations provide specific guidance on particular undergraduate and graduate programs in specialized academic areas ranging from teacher education to medical schools. A list of all of these organizations and their scope of authority may be found at http://www.chea.org/Directories/ regional.asp [19].

In addition to the accreditation programs noted above, there are other organizations that establish standards for themselves and institutions. One such organization is the Council for the Advancement of Standards in Higher Education (CAS). CAS is a consortium of forty professional organizations which has developed standards for forty-four functional areas. According to the CAS website, founded in 1979, the Council for the Advancement of Standards in Higher Education (CAS) [14] is the pre-eminent force for promoting standards in student affairs, student services, and student development programs. CAS creates and delivers dynamic, credible standards, guidelines, and Self-Assessment Guides that are designed to lead to a host of quality programs and services. CAS aims to foster and enhance student learning, development, and achievement [20].

CAS has developed a sophisticated set of processes through which standards are developed, approved and promulgated. New standards are developed based upon the perceived administrative functional area needs of professional associations who are members of the CAS consortium and may also be recommended by others who believe that an 
area needs more focus. For instance, The Association for Student Conduct Administration (ASCA) which is the professional association that deals with offices which administer student discipline may, through its representatives on the Board of Directors, ask for a revision of their standard due to major changes in Federal Law. Each existing standard is reviewed approximately every ten years and updates through the same process used for the development of new standards [17].

Each Standard Document contains a Contextual Statement, learning domains which are the basis for each standard, and a Self-Assessment Guide which can be used by end users to assess their programs. There are "standards" which are items required of all institutions and "guidelines" which may vary depending upon institutional and office size, complexity and budget [17]. Compliance with CAS standards is voluntary and determined through selfassessment.

While it is beyond the scope of this article to describe all of the standards of all accrediting agencies in the U.S., we have chosen to provide an example of one set of regional accreditation standards as provided by the Southern Association of Colleges and Schools Commission on Colleges [21]. At the heart of this process is an evaluation by the individual institution of how it operates and manages its academic, business and other operations. A reaffirmation of accreditation is performed every ten years as a regular practice. While this is true, if a reaffirmation visit or other processes uncover serious problems, a shorter time between investigations by SACSCC may take place. In order to achieve reaffirmation, an institution must successfully achieve:

1. Compliance with the Principle of Integrity,

2. Compliance with the Core Requirements,

3. Compliance with the Comprehensive Standards,

4. Compliance with additional Federal Requirements, and

5. Compliance with the policies of the Commission on Colleges [21].

These will be discussed below. In addition, the institution must develop a "Quality Enhancement Plan”. (QEP). The QEP identifies emerging issues at the institution and identifies a specific plan for the development and implementation for one large scale project or program to enhance student learning at the institution.

\subsection{Accreditation requirements}

2.2.1. Principle of Integrity: There is a short, simple statement with which each institution must comply if they are to be part of the SACS process. This is intended to assure that the institution will enter into the accreditation process openly and that it will be forthcoming and open to the public, its internal and external communities and with the Commission. Integrity in the reaffirmation process must be specifically acknowledged [21].

2.2.2. Core Requirements: The core requirements are comprised of 12 categories of basic institutional operational and management endeavors and requirements for inclusion of various types of academic content. Several of the 12 requirements are divided into sub-parts, all of which the institution must comply. SACS states that compliance with the core requirements, while essential, is not enough to result in accreditation or reaffirmation [21].

\subsubsection{Comprehensive Standards, According to} the Principles Statement: The Comprehensive Standards set forth requirements in the following four areas: (1) institutional mission, governance, and effectiveness; (2) programs; (3) resources; and (4) institutional responsibility for Commission policies. The Comprehensive Standards are more specific to the operations of the institution, represent good practice in higher education, and establish a level of accomplishment expected of all member institutions [21].

This is, by far, the most detailed set of requirements with which institutions must comply in order to win accreditation or reaffirmation. Within the four areas of requirements here are very specific compliance goals and specific statements about employee qualifications, board of trustee and presidential responsibilities, staffing levels, academic program requirements, student services support programs, financial management and many other focused requirements [21].

2.2.4. Federal Requirements: This section describes what institutions must do to comply with and make use of programs and policies described in the Higher Education Act, including specific reference to Title 4 which deals with Federal Financial Aid, as well as policies and regulations required by the Department of Education in relation to this law. Specifically there are requirements about having a number of policies and procedures, compliance with these policies and procedures, and having all of these policies and procedures in writing and accessible to all members of the institutional community, outside agencies and the general public [18] [21].

2.2.5. Policies of the Commission on Colleges: Here SACSCOC lays out its expectations with compliance by institutions and their officials with policies set by SACSCOC. Since this is a voluntary compliance program and each institution has a voice in the operation of the Commission, it is believed that institutions must also live within the policies of 
the Commission. While not detailed, these layout and define those expectations [21].

2.2.6. National Accreditation: According to Eaton, there are two broad types of "National" accreditation agencies in the United States [22]. These are four "Faith-Related" accreditation agencies which accredit "470 religiously affiliated or doctrinally based institutions", and seven "Career-Related" accreditation agencies which accredit "4298 mainly for-profit, career-based, single-purpose institutions, including distance learning colleges and universities”. As indicated previously, the ability for the students of any institution of post-secondary education in the United States to receive federal financial assistance is dependent on the institution which they seek to attend being accredited by one or more of the regional and/or national accreditation agencies. Many of the for-profit institutions which fall into the "career-related" category above have been criticized in the recent past for what many critics call deceptive recruitment practices, high default rates on student loans taken by students at these institutions, and the significant dependence on federal monies for their ability to operate. According to the National Council of State Legislatures [23]. there has been concern "about the quality of education these institutions offer, the amount of money in scholarships and loans they receive, the tactics they use to attract students, and the success of their graduates in finding jobs.” There was concern about the so-called 90-10 Rule. This rule, set by the federal government, limited the amount of revenue which could be obtained by students using federal financial aid to $90 \%$ of the total revenue from student fees. According to a Senate report, "Each year, many for-profit schools edge closer to the 90 percent line. Twenty-four percent of for-profit institutions had a $90 / 10$ ratio of 80 percent or above in 2007-8; just 2 years later, in 2009-10, the proportion jumped to 37 percent of all for-profit institutions [24]. This was of great concern not only to the federal government but to accreditors who feared that such a business model could lessen academic quality.

\section{Assessment and Accreditation in Portuguese Higher Education Institutions}

\subsection{Historical Development}

In Portugal we can define two phases in the assessment of higher education institutions. The first phase covered the period 1992-2005 and the second phase started in 2009. In 1992 the Council of Public Universities (CRUP) recognized the need on quality improvement of the higher education system and decided to follow the Dutch model at this time and an experiment was performed. The Ministry of
Education created the National Evaluation Council for Higher Education (CNAVES) and established the assessment of the two other sub-systems of higher education -public polytechnics and private universities. Two cycles of assessment took place. The first cycle occurred between 1995 and 2000 and a second cycle occurred between 2000 and 2005 [25].

According to Rosa et. al, "It never worked as planned, because comparisons between study programs were difficult due to reporting inconsistencies [25] [...] The government complained that review reports were obscure, seldom offering basis for the cancellation of poo quality programs "In 2006 and following a Report by the European Association for Quality Assurance in Higher Education (ENQA) the Portuguese government announced the dismantlement of CNAVES. Moreover, as stressed by Rosa [25]. The government wanted the new quality system to be internationally recognized, i.e. to comply with the European Standards and Guidelines for Quality Assurance and become a member of the European Register” [25].

The second phase started in 2007 when new legislation framework for HEIs was approved and the Agency for Assessment and Accreditation of Higher Education (A3ES) was created. The Board members were appointed in 2008 and the Agency finally started in 2009.

\subsection{Assessment and accreditation}

In 2007 (Law No. 38/2007, of August 16) was approved the legal system of higher education quality assessment. The preamble of Decree-Law $369 / 2007$ defines, as one of the axes of the evaluation and accreditation, "The requirement for achievement, by higher education institutions, of their own quality assurance systems, subject to certification". Under Law 38/2007, it is the responsibility of higher education institutions to adopt a policy of quality assurance and procedures for its pursuit.

According to Amaral (p. ix) [26]

"It is the mission of Agency for Higher Education Assessment and Accreditation (A3ES) to ensure the quality of higher education in Portugal, through the assessment and accreditation of higher education institutions and their study cycles, and the participation in the implementation of other assessments of a scientific nature, as well as to ensure the inclusion of Portugal in the European system of higher education quality assurance."

However it should be emphasized that the assessment and accreditation have complementary goals, in both cases with considerable social interest. Indeed, while the assessment, aiming at the monitoring and continuous quality improvement, 
represents what may be considered as the noblest function and the one with the greatest impact in the community, which is to promote the quality of activities related to teaching, research, cultural action and action in the exterior environment developed within institutions, the accreditation aims at guaranteeing the fulfilment of the minimum requirements that lead to the official recognition of the assessed study programme or institution [27].

According to Machado dos Santos "[...] presently, there is general consensus that assessment and accreditation processes are inseparable - they are two sides of the same coin" [27]. Moreover the author emphasizes:

“[...] currently, quality assurance systems tend to contain and articulate different complementary purposes, with more stress in one or the other as national systems of external quality assurance are geared predominantly towards procedures of monitoring and verification of compliance associated with the dimension of accreditation, or towards the functions of transparency and improvement, more linked to the dimension of an assessment geared towards production of validated, objective and understandable information about the institution and towards the systematic and sustained improvement of quality within the institution.

When A3ES started the assessment process, there were over 5200 study programmes (please see Table 1).

Table 1. Study programmes registered on DGES

\begin{tabular}{|l|c|c|c|c|c|}
\hline \multicolumn{7}{|c|}{$1^{\text {st }}$ cycle } & $\begin{array}{c}\text { Integrated } \\
\text { Masters }\end{array}$ & \multicolumn{2}{c|}{$2^{\text {nd }}$ cycle } & $3^{\text {rd }}$ cycle & Total \\
\hline Public Univ. & 515 & 115 & 1370 & 612 & 2612 \\
\hline Private Univ. & 459 & 15 & 544 & 85 & 1103 \\
\hline Total Univ. & 974 & 130 & 1914 & 697 & 3715 \\
\hline Public Poly. & 700 & & 435 & & 1135 \\
\hline Private Poly. & 271 & & 141 & & 412 \\
\hline Total Poly. & 971 & & 576 & & 1547 \\
\hline Total & 1945 & 130 & 2490 & 697 & 5262 \\
\hline
\end{tabular}

Source: A3ES: 2009 Action Plan [28]

Institutions submitted 4379 study cycles in operation to preliminary accreditation. Of these, $3623(82.7 \%)$ had a favourable decision on their preliminary, which is valid until their assessment within the scope of the first cycle of assessment/accreditation, with a five-year term, beginning in 2012. Institutions decided to propose the closure of 335 more study cycles, with the remaining 421 study cycles being sent to an immediate process of assessment/accreditation (please see Table 2).

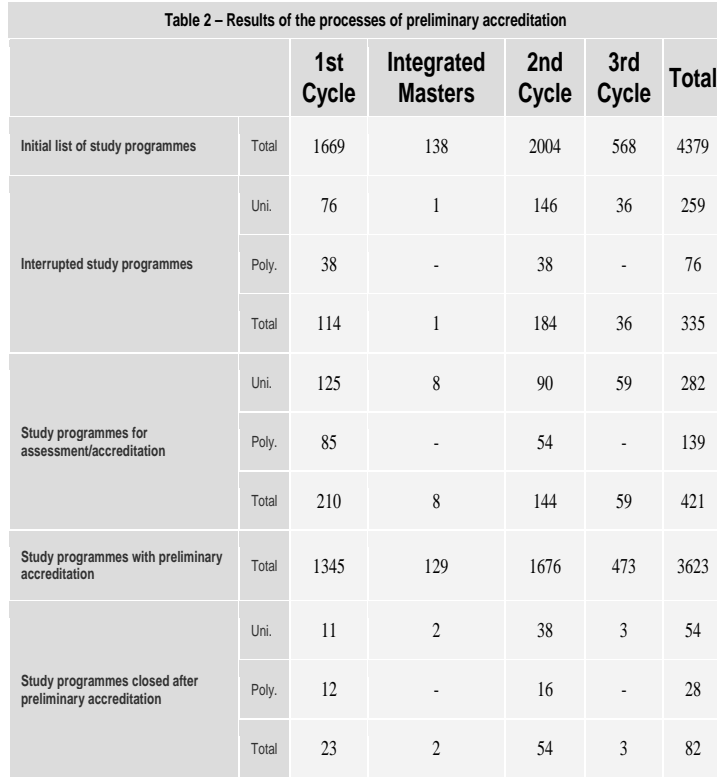

Source: A3ES: 2011 Action Plan [29]

However, it is interesting to note that the system is still in a process of adjustment of educational provision, as evidenced by the fact that institutions have already reported the closure of over 82 study cycles that had obtained preliminary accreditation; thus, presently, there are 3541 cycles studies with preliminary accreditation remaining.

Regarding students' participation in accreditation and the participation of professional organisations in accreditation during 2012, the experimental exercise integration of students as external evaluators will begin. Based on the results of the experimental exercise (namely, in the responsiveness manifested by institutions and in the students' effective participation), A3ES will consider the feasibility of formalising students' integration in those commissions."

The participation of students in the accreditation process can make a difference. According to Harrison, "A number of key factors have contributed to the increase in student feedback surveys including: the expansion of the higher education sector; expectations by quality assurance agencies; increased consumerism and marketisation; and increased concern over the quality of education [30]. [...] On the whole, however, there has been the realization that in order to improve the quality of the educational experience institutions need to take account of the experiences, attitudes and opinions of those who are on the receiving end of the education - the students - and enhancement is a partnership approach. [...] Student participation in quality processes underpins the validity and reliability of both internal and external review processes” [30].

The participation of professional bodies and other public associations is provided for by law, particularly in number 1 of article 13 of Law 
38/2007, of August 16, and subparagraph a) of no. 6 and no. 7 of article 7 of Decree-Law 369/2007, of November 5 .

Nevertheless, in a survey conducted by Rosa et. al "Overall the respondents thought as relevant all the Agency functions presented, with special emphasis being given to the accreditation of programs and institutions and to initiatives for including Portugal in the European higher education quality assurance system [25]. [...] Respondents stressed as main concerns with the Agency's activities, the excessive workload and bureaucracy of the quality assurance process; the excessive weight of accountability relative to quality improvement; and excessive financial costs" [25].

\subsection{Quality}

The concept of accreditation is associated with quality. There are attempts to improve quality within the higher education institutions in Portugal. According to Rosa et. al there is a consensus to set up a quality assessment system in the Portuguese higher education as "[...] result of several factors, including the Autonomy Acts, the questionable quality of a fast developing private sector, and European trends" [25].

The A3ES after consultation of the institutions, a Handbook for Auditing Process and Guidelines for Self-Assessment has been developed. In the year 2012, an experimental exercise of application of the audit model thus defined was developed, with the participation of five higher education institutions that have internal systems of quality assurance at an advanced stage of implementation and that have volunteered for the purpose.

However, there is no single, absolute and generalizable pattern of "quality" in and of higher education. Institutions have, and should have, different conceptions, which are adequate to their desirable visions and scenarios of development respecting, naturally, fundamental parameters already institutionalised in each country or in international agreements [20].

The impact of external review processes is recognized as stressed by Newton about the Finnish experience "Document analysis, interviews with senior managers, administrators and faculty members points to both direct and indirect evidence of the impacts of the audit process [31]. Examples of direct impact, both intended and unintended, include greater transparency, collegial learning about quality processes, and enhanced status of work. In contrast, indirect and emergent impact is evidenced by a reported increase in the routine discussion of quality issues in areas not included in the focus of the quality audits”' [31].

Regarding Internal Quality Systems of Portuguese higher education institutions Fonseca made a collection on the existence of internal quality systems [20]. Higher education institutions were also asked if they were having an internal quality assurance system (please see Table 3).

Table 3. Responses to the closed question "The institution has an internal quality assurance system?” - Yes/No

\begin{tabular}{|c|c|c|c|c|c|c|c|c|c|c|}
\hline \multirow[t]{2}{*}{ Typology of HEIs } & \multicolumn{2}{|c|}{ Yes } & \multicolumn{2}{|c|}{ No } & \multicolumn{2}{|c|}{ No, but... } & \multicolumn{2}{|c|}{$\begin{array}{l}\text { Yes+No, } \\
\text { but... }\end{array}$} & \multicolumn{2}{|c|}{ Total 0Us } \\
\hline & $\mathrm{Nr}$. & $\%$ & Nr. & $\%$ & Nr. & $\%$ & Nr. & $\%$ & & $\%$ \\
\hline Public Universities & 74 & 67.89 & 35 & 32.11 & 9 & 8.26 & 83 & 76.15 & 109 & 100.00 \\
\hline Public Polytechnics & 34 & 43.59 & 44 & 56.41 & 40 & 51.28 & 74 & 94.87 & 78 & 100.00 \\
\hline Private Universities & 27 & 61.36 & 17 & 38.64 & 6 & 13.64 & 33 & 75.00 & 44 & 100.00 \\
\hline Private Polytechnics & 31 & 51.67 & 29 & 48.33 & 11 & 18.33 & 42 & 70.00 & 60 & 100.00 \\
\hline $\begin{array}{l}\text { Opent Univ. + Military } \\
\text { HEIs + Catholic Univ. }\end{array}$ & 17 & 50.00 & 17 & 50.00 & 11 & 32.35 & 28 & 82.35 & 34 & 100.00 \\
\hline Total & 183 & 56.31 & 142 & 43.69 & 74 & 22.77 & 257 & 79.08 & 325 & 100.00 \\
\hline
\end{tabular}

By Organisational Units: Faculties and Schools

Source: Fonseca (2010): Acreditação Ano Zero. Os Sistemas Internos de Garantia de Qualidade das Instituições de Ensino Superior em Portugal [32]

Table 4 summarises the fields covered by quality:

Table 4. Domains covered by Internal Quality Assurance

\begin{tabular}{lcc}
\hline & Nr. & $\%$ \\
\hline Assessment of student satisfaction & 270 & 83.08 \\
\hline Assessment of faculty & 241 & 74.15 \\
\hline Assessment of education provision (study programmes) & 238 & 73.23 \\
\hline Assessment of teaching/learning & 218 & 67.08 \\
\hline Assessment of employability - survey to former & 140 & 43.08 \\
\hline students/Alumni/employers & & \\
\hline Assessment of administrative services & 112 & 34.46 \\
\hline Assessment of scientific research & 109 & 33.54 \\
\hline Assessment of management/administration & 91 & 28.00 \\
\hline Assessment of other services of student support & 81 & 24.92 \\
\hline Assessment of the institution objectives/mission & 78 & 24.00 \\
\hline The assessment covers the whole institution & 55 & 16.92 \\
\hline Assessment of internationalisation & 48 & 14.77 \\
\hline Total of responses of OUs & 325 & 100.00 \\
\hline
\end{tabular}

(Organisational Units - Faculties and Schools - that refer each domain)

Source: Fonseca 2010: Acreditação Ano Zero [32]. Os Sistemas Internos de Garantia de Qualidade das Instituições de Ensino Superior em Portugal [32].

According to Fonseca [32]:

"Procedures related to employability with surveys to former students and/or employers are relevant in 
public institutions, universities and polytechnics, even if with values that are slightly above the unity, whereas the remaining institutions record values that are below the unity".

The assessment of administration and management and administration services are referred to more significantly by private institutions, universities and polytechnics, and by the group composed of the Open University, Military HEIs and Portuguese Catholic University. Public polytechnic institutes, being the institutions that use more assessment instruments of compliance of the ISO Norm type, do not stand out, paradoxically, in the assessment of administrative services.”

Some authors fear that quality assurance should not be converted into a bureaucratic burden, with the standardisation of systems and destruction of creativity potential of universities. The quality assurance system cannot create work instead of quality. Rather, the processes associated with it should be a component in the development of a culture of quality, enhancing the opportunities for internal debate and reflection, building visions and strategies of development in HEIs [20]. For instance as stated by Newton "For the "quality research" community, as has been argued, "impact", "improvement" and "enhancement" are underresearched and under-theorised [31]. Moreover, the quality revolution has been marked by a lack of "impact" research, particularly the impact of quality assurance processes on academic practice, the student experience and student learning” [31].

Concerning quality and quality culture Machado dos Santos suggests the following as key factors for a quality culture [27]:

$>$ the appropriation of the process and the involvement of the academic community;

$>$ the recognition, by the internal actors, of the need for a quality system (of a nonbureaucratic nature);

$>$ a focus on the changing of people behaviour and not only on the monitoring and review mechanisms;

$>$ clarity of purpose;

$>$ the centrality of students, both in learning processes and in their involvement in the assessment processes;

$>$ the encouragement of cooperation and partnership work;

$>$ the focus on the involvement of the internal community and teamwork;

$>\quad$ an inspiring and motivating leadership;

$>$ the responsiveness to critical remarks made by external evaluators;

$>$ an integrated and continuous process of self-reflection;

$>$ the creation of an environment that is adequate for improvement initiatives, even when involving risk-taking
Moreover the author states by "It should be added that a good quality assurance system is both a management tool for the institution and a practical system for the improvement of daily activities; hence, the work with quality should not be reduced to inspection and control rules. The system should, therefore: - be based on procedures that are closely associated with the very learning processes and learning environments; - be a driver for all staff and students and engage them in the work related to quality” [27].

Authors such as Ingle stated the benefits of the Quality process "First, it provides the opportunity to undertake a thorough examination of all sections and operations within the area [33]. The development of the SAR ends up being a quality enhancement process in itself, and ongoing anecdotal and other evidence confirms the value of the process to both the area under review and the university. The second benefit of the review process is that it provides an update and endorsement to senior management and the wider university community of the commendable work being undertaken in the area. There are few fora where this kind of self-promotion can take place, and this particular aspect of the review process is always commented on favourably by internal quality review committees. The third benefit is the opportunity to avail of national and international expert peer advice via the recommendations for improvement provided in the PRG report” [33].

Nevertheless, the authors would like to stress the answers to the survey conducted by Rosa et. al, the answers "Respondents privileged the improvement function over the accountability function, and internal quality assurance processes over the external ones. [...] and the possibility of an excessive weight to the accountability function over the quality improvement one” [25].

\section{Final Thoughts}

Obviously this article cannot describe all of the intricacies of the American accreditation and quality assessment programs. With a system that is so complex, divided into fifty state systems and several accreditation regions, with institutions that vary in size from 20 to 400,000 students both in residence and in distance education programs, and with institutions that have multiple campuses and centres, it is very difficult to make one system fit all.

Here, there is constant change and re-visioning among both the regional and national accreditation agencies. The U.S. Department of Education has, over times, and depending on whether there is a Republican or Democratic president, sought to exercise more or less control over the process. Because higher education is primarily governed by state law and overseen by state management agencies which vary in authority and responsibility, this too 
adds to the need for constant review of the systems in place.

The concerns about for-profit higher education in the U.S. have increased dramatically in recent years and the U.S. Congress has investigated these institutions and passed a number of laws to govern and oversee them. This level of concern and this increased oversight has resulted in drops in enrollment at some of these institutions and concerns about whether federal financial aid dollars are being used properly. The authors believe that these institutions will face increased scrutiny and that changes in the national accreditation process may occur as a result.

In the European system, using Portugal as an example of one system within the European Union, we note that these too are a complex set of systems seeking common ground. The agenda of HE (higher education) is being dominated by the creation of the European Higher Education Area and the Bologna. There are different perspectives of higher education assessment systems at the European level based on independent accreditation agencies and others where quality audit agencies have been replaced by agencies based on accreditation.

We hope, however, that this paper gives the reader a starting point with which to begin the process of understanding the American and Portuguese systems of accreditation.

\section{References}

[1] Machado-Taylor, M. L. (2011). Complex adaptive systems: A trans-cultural undercurrent obstructing change in higher education. International Journal of Vocational and Technical Education, 3(2), 9-19.

[2] Stensaker, Bjorn (2013). Questioning the idea of the Ivory Tower: Organizational identity as a mediator between continuity and change. Working Paper Series. UIO: Faculty of Educational Sciences, University of Oslo

[3] Neave, G. (2012). The evaluative state, institutional autonomy and reengineering higher education in Western Europe: The prince and his pleasure, Basingstoke/ New York, Palgrave Macmillan

[4] Amaral, A. \& Rosa, M.J. (2008). International review of the Portuguese quality assurance system. In EUA (Ed.), Implementing and Using Quality Assurance: Strategy and Practice - A Selection of Papers from the 2nd European Quality Assurance Forum, EUA Case Studies 2008, European University Association, Brussels, pp. 74-79.

[5] Vébra, V; Sceutle, H (2012) International Accreditation - Effects of national and cultural differences In Crozier, F.; Kelo, M; Loukkola, T.; Michalk, B.; Päll, A. Palomares, F. M. G.; Ryan, N.; Stensaker, B. ; Van de Velde, L. How does quality assurance make a difference? (a selection of papers from te $7^{\text {Th }}$ European Quality Assurance Forum
[6] Brittingham, Barbara (2009) "Accreditation in the United States: How Did We Get to Where We Are?” New Directions for Higher Education no. 145 (Spring 2009), p. 22

[7] Ewell, Peter T. (2008) "U.S. Accreditation and the Future of Quality Assurance,” CHEA.

[8] Harvey, L., \& Williams, J., 2010a, 'Editorial: Fifteen years of Quality in higher education', Quality in higher education, 16(1), pp. 3-36.

[9] Dickeson, Robert C. (2009) "Recalibrating the Accreditation? Federal Relationship" Washington DC: Council for Higher Education Accreditation, January 27, 2009.

[10] Eaton, Judith S. (2010) “Accreditation's Accidental Transformation,” InsideHigherEd, July 20, 2010.

[11] Abkowitz, A. (2007). The student trap. Creative Loafing Atlanta. Accessed at http://clatl.com/atlanta/thestudent-trap/Content?oid $=1268448$

[12] Miller, B. (2010). What got the ED. Dept. so mad about American Intercontinental University and its accreditor? The Quick \& the ED: Education Sector at American Institutes for Research. Accessed from http://www.quickanded.com/2010/04/more-informationabout-american-intercontinental-university.html

[13] ENQA (2005). Standards and guidelines for quality assurance in the European Higher Education Area, European Association for Quality Assurance in Higher Education, Helsinki.

[14] Schwarz, S. and Westerheijden, D. (2004). Accreditation and Evaluation in the European Higher Education Area. Dordrecht: Kluwer Academic Press.

[15] Serrano-Velarde, K. \& Hopbach, A. (2007). European politics of quality assurance and the introduction of the Standards and Guidelines for Quality Assurance in the European Higher Education Area. In HRK (Ed.). The Quality Assurance System for Higher Education at European and National Level, Bologna Seminar Berlin, 15/16 February 2007, German Rectors' Conference, Bonn, pp. 29-62.

[16] Hazelkorn, E. (2011). Globalization and the Reputation Race in Rankings and the Reshaping of Higher Education: the Battle for World Class Excellence. Palgrave MacMillan. p.6

[17] Eaton, J. S. (2014). Recent trends in U.S. accreditation in M.J. Rosa, \& A. Amaral. Quality assurance in higher education: Contemporary debates. London: Palgrave MacMillan. pp. 149-159.

[18] U.S. Department of Education (2006). A test of leadership: Charting the future of US higher education: A report of the commission appointed by Secretary of Education Margaret Spellings, https://www2.ed.gov/about/ bdscomm/list/hiedfuture/reports/pre-pub-report.pdf. September 2014). 
[19] Council for Higher Education Accreditation (CHEA). (nd) (20 2014), http://www.chea.org/Directories/regional.asp.

[20] Council for the Advancement of Standards in Higher Education (CAS). (nd). http://www.cas.edu/ 20 September 2014).

[21] Principles of Accreditation: Foundations for Quality Enhancement (2012). Southern Association of Colleges and Schools Commission on Colleges. http://www.sacscoc. org/pdf/2012PrinciplesOfAcreditation.pdf. (22 September 2014).

[22] Eaton, J.S. (2012). Accreditation and recognition in the United States. Council for Higher Education Accreditation.

http://www.chea.org/pdf/AccredRecogUS_2012.pdf. （15 November 2014)

[23] For-profit colleges and universities (2013). http://www.ncsl.org/research/education/for-profit-collegesand-universities.aspx (15 November 2014)

[24] For profit higher education: The failure to safeguard the Federal investment and ensure student success. (2012). Report of the United States Senate Health, Education, Labor and Pensions Committee . http://www.help.senate.gov/imo/media/for_profit_report/P artI-PartIII-SelectedAppendixes.pdf (21 November 2014)

[25] Rosa, M. J.; Santos, C. Cardoso, S. ; Amaral, A. 2010) The Portuguese System of Quality assurance - new deveolpments and expectations. Paper presented at the $4^{\text {th }}$ European Quality Assurance Forum- Creativity and Diversity: Challenges for Quality Assurance Beyond 2010.

[26] Amaral, A. (2011) Prefácio in Santos, Sérgio Machado dos. Análise Comparativa dos Processos Europeus Para A Avaliação e Certificação De Sistemas Internos de Garantia da Qualidade. Lisboa, Colecção/Série: A3ES READINGS No 1 .

[27] Santos, Sérgio Machado dos (2011) Análise Comparativa dos Processos Europeus Para A Avaliação e Certificação De Sistemas Internos de Garantia da Qualidade. Colecção/Série: A3ES READINGS Nº1.

[28] A3ES (2009). Plano de Actividades para 2009, Agência de Avaliação e Acreditação do Ensino Superior, Lisboa. $\quad$ http://www.a3es.pt/pt/estudos-edocumentos/documentos.

[29] A3ES (2011). Plano de Actividades para 2009, Agência de Avaliação e Acreditação do Ensino Superior, Lisboa. $\quad$ http://www.a3es.pt/pt/estudos-edocumentos/documentos.

[30] Harrison , T. (2012) Gathering student feedback: How can it make a difference? In In Crozier, F.; Kelo, M; Loukkola, T.; Michalk, B.; Päll, A. Palomares, F. M. G.; Ryan, N.; Stensaker, B. ; Van de Velde, L. How does quality assurance make a difference? (a selection of papers from te $7^{\text {Th }}$ European Quality Assurance Forum
[31] Newton, Jethro (2012) Is quality assurance leading to enhancement? In Crozier, F.; Kelo, M; Loukkola, T.; Michalk, B.; Päll, A. Palomares, F. M. G.; Ryan, N.; Stensaker, B. ; Van de Velde, L. How does quality assurance make a difference? (a selection of papers from te $7^{\text {Th }}$ European Quality Assurance Forum

[32] Fonseca, Madalena (2010) 2010: Acreditação Ano Zero. Os Sistemas Internos de Garantia de Qualidade das Instituições de Ensino Superior em Portugal.

[33] Ingle, Sarah (2012) Institutional integration of quality assurance and enhancement in an Irish university context In Crozier, F.; Kelo, M; Loukkola, T.; Michalk, B.; Päll, A. Palomares, F. M. G.; Ryan, N.; Stensaker, B. ; Van de Velde, L. How does quality assurance make a difference? (a selection of papers from te $7^{\text {Th }}$ European Quality Assurance Forum 